\title{
Asetamiprid ve d-Tübokürarin'in Kurbağa Sinir Dokusu Üzerine Etkilerinin İncelenmesi (I: Oksidatif Potansiyel)
}

\author{
Yusuf ÇAMLICA, Salih Cüfer BEDİ, Serap YALIN
}

\section{ÖZ}

Bu çalışmada, asetamiprid ve d-tübokürarin'in Rana ridibunda siyatik siniri üzerine oksidatif stres etkisinin incelenmesi amaçlanmıştır. Bu amaçla kurulan deneylerde, 40 adet kurbağa siyatik sinir preparatı kullanılmıştır. Kurbağalar, spinal hale getirildikten sonra siyatik sinirler izole edilmiştir. Sinirlere, 120 dakika boyunca $1 \times 10^{-3}, 1 \times 10^{-4}, 1 \times 10^{-5}$ ve $1 \times 10^{-6} \mathrm{M}$ olmak üzere dört farklı konsantrasyondaki asetamiprid çözeltileri uygulanmıştır. Bunun yanı sıra siyatik sinir dokuları, $1 \times 10^{-3}$ $\mathrm{M}$ asetamiprid ile $1 \times 10^{-2} \mathrm{M}$ d-tübokürarin karışımı, $1 \times 10^{-5}$ $\mathrm{M}$ asetamiprid ile $1 \times 10^{-4} \mathrm{M}$ d-tübokürarin karışımı ve $1 \times 10^{-6}$ $\mathrm{M}$ asetamiprid ile $1 \times 10^{-5} \mathrm{M}$ d-tübokürarin karışımında 120 dakika bekletilmiştir. Kontrol grubundaki sinir dokuları, 120 dakika süresince Ringer çözeltisinde bekletilmiştir. Tüm deney gruplarında agonist ve antagonist etkileri eşit sayıda denek üzerinde çalışılmıştır $(N=5)$. Kurbağalarda oksidatif stresi değerlendirmek için, katalaz (CAT) ve asetilkolinesteraz (AChE) aktiviteleri ile malondialdehit (MDA) düzeyleri ölçülmüştür.
Yapılan biyomarkır analizleri sonucunda, $1 \times 10^{-3} \quad \mathrm{M}$ asetamiprid'in siyatik sinirde, biyokimyasal parametrelerden CAT ve AChE aktivitesini kontrol grubuna göre önemli biçimde azalttığı gözlenmiştir $(P<0.05)$. Buna karşılık aynı konsantrasyondaki insektisitin, sinir dokuda MDA seviyesini kontrol grubuna göre önemli biçimde arttırdığı tespit edilmiştir $(P<0.05)$.

Asetamiprid'in siyatik sinir dokusunda, biyokimyasal parametrelerden CAT ile AChE'yi anlamlı şekilde düşürmesi, MDA'yı ise önemli biçimde yükseltmesi, bu insektisitin yüksek konsantrasyonda periferik sinirler üzerine oksidatif strese bağlı hasar meydana getirdiğini göstermektedir.

Anahtar kelimeler: Asetamiprid, d-tübokürarin, sinir doku, oksidatif stres, kurbağa

$\mathrm{Bu}$ çalışma 12.02.2016 tarihinde kabul edilen "Acetamiprid ve d-tubocurarine’nin Rana ridibunda siyatik siniri üzerine etkilerinin incelenmesi" isimli tez çalışmasından hazırlanmıştır.
Yusuf ÇAMLICA, Salih Cüfer BEDİZ

Mersin Üniversitesi, Fen Edebiyat Fakültesi Biyoloji Bölümü, Mersin

Serap YALIN

Mersin Üniversitesi, Eczacillk Fakültesi, Biyokimya Anabilim Dal, Mersin

\section{Sorumlu yazar:}

Yusuf CAMLICA

Tel: $03243610001-4601$

Gsm: 05055985186

Fax: 03243610046

E-posta:ycamlica@mersin.edu.tr,ycamlica@yahoo.com

Submitted / Gönderilme: 27.06.2016

Accepted / Kabul: 14.08.2016
Revised / Düzeltme: 11.08.2016

\section{GíRIŞ}

İnsektisitler, bitki veya hayvanlara zarar veren organizmaların öldürülmesi, uzaklaştırılması ya da kontrol edilmesi amacıyla, dünya çapında yaygın olarak kullanılan kimyasal maddelerdir. Bunların tipi, dozu ve çevrede bulunma süresine bağlı olarak kalıntıları, yararlı böcekler gibi hedef olmayan türlerin üreme ve hayatta kalma oranlarında azalmaya neden olabilmektedir (1). Ürün zararlılarına karşı yaygın olarak kullanılan insektisitler biyolojik kökenli olabildiği gibi, sentetik kökenli de olabilirler (2). Özellikle tarımda 1930'lu yllardan itibaren, modern sentez kimyasındaki devrim ile birlikte çeşitli sentetik insektisitler üretilmiştir (1). Her yıl Dünyada 300.000 kişi kendilerinin kullandığı kırsal pestisit kullanımından zehirlenip ölmektedir. Gelişen 
dünyamızda tarım ilaçları yaygın olarak küçük ölçekli tarımsal uygulamalarda kullanılmaktadır. $\mathrm{Bu}$ zehirlenme sanayileşmiş ülkelerde çok daha az görülmektedir (3). Zirai ilaç sektörü, çevre ve tüketiciler için güvenli olan yeni bitki koruma faktörlerinin geliştirilmesi için, artan talep ve aynı zamanda ürün zararlılarının ortaya çıkmasıyla ilgili mücadele konusunu da içeren büyük bir gelişimle karşı karşıyadır (4).

İnsektisitler klorlu hidrokarbonlular, organofosforlu bileşikler, metilkarbamatlar, piretroidler ve neonikotinoid insektisitler olmak üzere beş ana gruba ayrilırlar. Neonikotinoidler, hem bir nitrometilen ve nitroimin, hem de siyanoimin grubuna sahip yeni sentetik insektisit grubudur (5). Nitrometilenler ilk olarak 2-pirimidin yapısında olan ve zayıf insektisit etkisine sahip bir bileşikten köken almıştır. Bu prototip üzerindeki ilk yapı-aktivite çalışması, nithiazinin bulunmasını sağlamıştır (6).

Yapısal olarak nikotine benzerlik gösteren neonikotinoidler, etkileri bakımından da nikotine benzerlik gösterir. Nikotin yüzlerce yıl geleneksel tarımda doğal bir insektisit olarak kullanılmıştır. Nikotin ile ilgili yapılan deneylerde, nikotinin böcek nikotinik asetilkolin reseptörlerine (nAChR) bağlanarak insektisit etkisi gösterdiği ortaya çıkarılmıştır (7). Asetamiprid, ürün zararlılarına karşı yaygın olarak kullanılan bir neonikotinoid insektisittir (8).

Böcek gelişimini etkileyen insektisitlerin dişında kalan insektisitlerin hemen hemen hepsi nörotoksik maddeler olup, başta böcekler olmak üzere canlıların sinir sistemi üzerine etki ederler (1). Neonikotinoid insektisitler nAChR üzerine etki eden bileşiklerdir. $\mathrm{Bu}$ insektisitler özellikle yaprak bitleri, ak sinekler ve bitki pireleri gibi hemipteran haşere türlerinin yanı sıra, ticari olarak birçok koleopteran ve bazı lepidopteran haşere türlerinin kontrolünde kullanılmaktadır. $\mathrm{Bu}$ insektisit sınıfının en önemli elemanı imidakloprid'dir (9). İnsektisitlerin hedef bölgeleri, canlı organizmada insektisit molekülünün etkileşime girerek toksik etkilerini ortaya çıkarabilecekleri spesifik biyokimyasal veya fizyolojik bölgelerdir (10).

Omurgalı hayvanlar insektisitlere maruz kaldıkları zaman, reaktif oksijen türleri (ROS) ve reaktif nitrojen türlerinde (RNS) artış meydana gelmektedir (11). Reaktif aracılar olarak da tanımlanan bu bileşikler, oksijenin kısmen indirgenmesi ile oluşan hidrojen peroksit, süperoksit anyonlar, hidroksil radikalleri ve nitrik oksittir. DNA, protein ve hücre membranı gibi biyolojik sistemlerle reaksiyona giren RNS ve ROS'lar, bu sistemlerde hasar oluştururlar (12). Fakat vücudun kendisinde bulunan antioksidan enzimler, bu radikalleri, detoksifiye ederek zararlı etkilerini ortadan kaldırabilirler.
Süperoksit dismutaz (SOD), CAT, glutatyon peroksidaz (GPx) gibi enzimler, reaktif oksijen radikallerini yok ederek, insektisitlerin serbest radikal oluşturma etkilerine karşı hücreleri korudukları anlaşılmıştır (13). Antioksidan enzimler, daha az aktif radikal oluşmasına yol açarak veya serbest radikal zincir reaksiyonunun proteinler, lipidler, karbonhidratlar ve DNA üzerine hasarını azaltarak oksidatif stresin şiddetini bastırmaya yardımcı olan maddelerdir (14). Fizyolojik koşullarda hücreler, serbest radikallerin neden olabileceği oksidatif hasara karşı antioksidan savunma sistemleri tarafindan korunur. CAT enzimi, $\mathrm{H}_{2} \mathrm{O}_{2}$ 'yi su ve oksijene parçalarken, AChE enzimi, asetilkolini (ACh) yıkıma uğratarak asetat ve tiyokoline dönüştürür (13). Fakat bu antioksidan sistemin koruyucu kapasitesi sınırlı olup, ihtimaldir ki ROS ve RNS'lerin çok fazla üretildiği patolojik durumlarda etkisiz kalabilir ve bu yeni durum oksidatif stres olarak isimlendirilir (15). İnsektisitler, oksidatif strese bağlı serbest radikal üretimine ve lipit peroksidasyonuna (LPO) yol açarak doku ve hücrelerde hasar meydana getirirler. Yapılan birçalışmada, insektisitlerin fare ve tavuklarda hepatik LPO'yu yükselttiği, serbest radikal meydana getirmesine bağlı olarak, dokularda oksidatif stres oluşturduğu gösterilmiştir (16). Pestisitler tarafından indüklenen ROS oluşumu, oksidatif strese neden olur ve serbest radikal üretimi ile antioksidan sistem arasında dengesizlik meydana getirir $(17,18)$.

$\mathrm{Bu}$ çalısmanın amacı, neonikotinoid bir insektisit olan asetamiprid ve bir neonikotinoid antagonisti olan d-tübokürarin'in, kurbağa siyatik sinirinde CAT, AChE ve MDA gibi biyokimyasal parametreler üzerine toksik etkilerinin belirlenmesidir. Bu çalışmayla, yeni üretilen bir insektisit olan asetamiprid'in Rana ridibunda siyatik siniri üzerine etkisi belirlenerek, insektisitlerin çevre ve insan sağlı̆̆ üzerine olumsuz etkilerini azaltacak yeni uygulamaların geliştirilmesine katkı yapılması beklenmektedir.

\section{GEREÇ ve YÖNTEM}

\section{Deney Hayvanları}

Deneylerde Mersin Mezitli Deresinden yakalanan ve ağırlıkları 45-55 g arasında değişen 40 adet kurbağa (Rana ridibunda) kullanılmıştır. Kurbağalar yakalandıktan sonra, içerisinde su bulunan akvaryumda laboratuvar koşullarına uyum sağlamaları amacı ile 5 gün boyunca dinlendirilmiş, sıcaklık ise $25-27^{\circ} C^{\prime}$ ye ayarlanmıştır $(19,20)$. Kurbağalar spinal hale getirilmiş, daha sonra omurilik ortadan kaldırılmıştır. Bunun için kurbağalar kulak arkasından kesilerek beyin uzaklaştırılmış, daha sonra herhangi bir uyuşturucu madde kullanmadan iğne yardımıyla vertebral 
kolona girilerek omurilik tahrip edilmiştir (21). Refleks merkezi ortadan kaldırılan ve hareketsiz hale getirilen kurbağalardan, diseksiyonla 40 adet siyatik sinir çıkarılmış ve Ringer çözeltisine alınmıştır. Bu çalışmada kullanılan deney hayvanları için Mersin Üniversitesi Hayvan Deneyleri Yerel Etik Kurulu'nun (HADYEK) 27.03.2014 tarih ve 2014/10 sayılı kararı ile etik kurul izni alınmıştır. Kurbağalara yapılan tüm işlemlerde National Institutes of Health (NIH) tarafindan hazırlanan laboratuvar hayvanlarının bakım ve kullanım rehberinde belirtilen kriterler uygulanmıştır.

\section{Kimyasallar}

Deneylerde neonikotinoid insektisitlerden asetamiprid $\left(\mathrm{C}_{10} \mathrm{H}_{11} \mathrm{ClN}_{4} ; 33674\right.$, Sigma $)$ ve bir neonikotinoid antagonisti olan d-tübokürarin $\left(\mathrm{C}_{37} \mathrm{H}_{42} \mathrm{Cl}_{2} \mathrm{~N}_{2} \mathrm{O}_{6} 5 \mathrm{H}_{2} \mathrm{O} ; \mathrm{T} 2379\right.$, Sigma $)$ kullanılmıştır. Siyatik sinirlere, 120 dakika boyunca $1 \times 10^{-3}$, $1 \times 10^{-4}, 1 \times 10^{-5}$ ve $1 \times 10^{-6} \mathrm{M}$ olmak üzere Ringer çözeltisinde $\left(\mathrm{NaCl}, 115 \mathrm{mM} ; \mathrm{KCl}, 2,47 \mathrm{mM} ; \mathrm{CaCl}_{2}, 1,8 \mathrm{mM} ; \mathrm{Na}_{2} \mathrm{HPO}_{4}\right.$, $2,15 \mathrm{mM}, \mathrm{pH}=7$ ) hazırlanan dört farklı konsantrasyondaki asetamiprid çözeltileri uygulanmıştır. Çalışmamızda, konsantrasyona bağlı akut toksisitenin belirlenmesi hedeflenmiştir. Asetamiprid'in $\mathrm{LC}_{50}$ değeri (Lethal concentration) $1000 \mu \mathrm{g} / \mathrm{mL}$ 'dir. Bu nedenle, deneylerde en yüksek insektisit konsantrasyonu olarak, asetamiprid'in $\mathrm{LC}_{50}$ değerinin \%22'sine karşılık gelen $1 \times 10^{-3} \mathrm{M}$ kullanılmıştır. Diğer konsantrasyonlar ise, $\mathrm{LC}_{50}$ değerinin $\% 2,2, \% 0,22$ ve $\% 0,022$ 'si olarak belirlenmiştir $(22,23)$. Bunun yanı sıra siyatik sinir dokuları, Ringer çözeltisinde hazırlanan $1 \times 10^{-3}$ $\mathrm{M}$ asetamiprid ile $1 \times 10^{-2} \mathrm{M}$ d-tübokürarin karışımı, $1 \times 10^{-5} \mathrm{M}$ asetamiprid ile $1 \times 10^{-4} \mathrm{M}$ d-tübokürarin karışımı ve $1 \times 10^{-6}$ $\mathrm{M}$ asetamiprid ile $1 \times 10^{-5} \mathrm{M}$ d-tübokürarin karışımında 120 dakika bekletilmiştir. Kontrol grubundaki siyatik sinir dokuları ise, 120 dakika süresince sadece Ringer çözeltisinde bekletilmiştir. Tüm deney gruplarında agonist ve antagonist etkileri eşit sayıda denek üzerinde çalışılmıştır $(N=5)$.

\section{Biyokimyasal Analizler}

CAT aktivitesi tayini Aebi tarafından tarif edilen yönteme göre yapılmıştır (24). Bu yöntem, $\mathrm{H}_{2} \mathrm{O}_{2}$ substratının CAT ile enzimatik yıkımının 240 nm'de izlenmesi esasına dayanmaktadır. Enzim aktivitesi, ünite $(\mathrm{U}) / \mathrm{g}$ protein cinsinden hesaplanmıştır.

MDA ölçümü, LPO ürünlerinden en stabili olan MDA’nın, tiyobarbitürik asit ile arasındaki reaksiyon sonucu ortaya çıkan pembe kırmızı renkli çözelti absorbansının, spektrofotometrik yöntemler kullanılarak değerlendirilmesi esasına dayanmaktadır (25). MDA düzeyleri, nmol/g protein şeklinde ifade edilmiştir.
Protein ölçümü, Lowry yöntemine göre standart olarak bovin serum albumin kullanılarak yapılmıştır (26). Bu yönteme göre, alkali çözeltide bakır-protein kompleksi oluşmaktadır. $\mathrm{Bu}$ kompleks, fosfomolibdatfosfotungstat reaktifini (folinciocalteus-phenol reaktifi) redüklemekte ve koyu mavi bir renk meydana gelmektedir. Oluşan rengin koyuluğu, ortamdaki protein konsantrasyonu ile doğru orantılı olarak değişmektedir.

AChE tayininde, ürün olarak açı̆̆a çıkan tiyokolin ile benzoik asit (5,5'-ditiyobis-(2-nitrobenzoik asit) - DTNB)'in reaksiyonu sonucu sarı renk veren, 5-tiyo 2-nitrobenzoik asit oluşmaktadır. Tepkime sırasında oluşan rengin şiddeti, $412 \mathrm{~nm}$ dalga boyunda spektrofotometrede (Analyticjena SPECORD 50) ölçülmüştür (27).

Asetilkolin $\longrightarrow$ AChE
Tiyokolin + DTNB Tiyokolin + Asetat
$\longrightarrow$ 5-tiyo 2-nitrobenzoik asit (sarı renk)

\section{İstatistiksel Değerlendirmeler}

$\mathrm{Bu}$ çalışmada elde edilen verilerin istatiksel değerlendirilmesi için, bu amaçla hazırlanmış paket programlar (Microsoft Excel ve SPSS 17.0) kullanılmıştır. Çalışılan bütün parametreler için önemlilik testi SNK (Student Newman Keuls) istatistik programı kullanılmıştır. Sürekli ölçümlere ait normallik kontrolleri, Shapiro Wilk testi ile test edilmiş ve verilerin normal dağılım gösterip göstermediğine bakılmıştır. Normal dağılım gösteren verilerde, gruplar arası farklılık olup olmadığı varyans analizi (One Way ANOVA) ile test edilmiştir. Normal dağılım göstermeyen verilerde ise, gruplar arasında farklılık olup olmadığ Kruskal Wallis testi kullanılarak saptanmıştır. Grup karşılaştırmaları ise, Bonferroni ve Dunn testleri uygulanarak yapılmıştır. İstatistiksel anlamlı farklılık olarak $P<0.05$ alınmıştır (28).

\section{BULGULAR}

Siyatik sinirin 120 dakika boyunca $1 \times 10^{-3} \mathrm{M}$ asetamiprid ile muamele edilmesi sonucunda, biyokimyasal parametrelerden CAT aktivitesinin kontrol grubuna göre anlamlı biçimde azaldığı gözlenmiştir (Şekil 1). Siyatik sinirin, 120 dakika boyunca $1 \times 10^{-4}, 1 \times 10^{-5}, 1 \times 10^{-6} \mathrm{M}$ asetamiprid çözeltileri ve $1 \times 10^{-3} \mathrm{M}$ asetamiprid ile $1 \times 10^{-2} \mathrm{M}$ d-tübokürarin karışımına maruz bırakılması sonucunda, CAT aktivitesinde görülen azalmaların ise, istatistiksel bakımdan anlamlı olmadığı tespit edilmiştir. Buna karşıllı, sinirlerin $1 \times 10^{-6} \mathrm{M}$ asetamiprid ile $1 \times 10^{-5} \mathrm{M}$ d-tübokürarin karışımı ve $1 \times 10^{-5} \mathrm{M}$ asetamiprid ile $1 \times 10^{-4} \mathrm{M}$ d-tübokürarin karışımında bekletilmeleri sonucu, 
CAT aktivitesinde meydana gelen artış anlamlı değildir (Şekil 1).

Siyatik sinirin, 120 dakika boyunca $1 \times 10^{-3} \mathrm{M}$ asetamiprid ile muamele edilmesi sonucunda, biyokimyasal parametrelerden MDA düzeyinin kontrol grubuna göre anlamlı biçimde yükseldiği tespit edilmiştir (Şekil 2). Buna karşıllk siyatik sinirin, 120 dakika boyunca $1 \times 10^{-4}, 1 \times 10^{-5}$ ve $1 \times 10^{-6} \mathrm{M}$ asetamiprid çözeltileri ile ayrı ayrı muamele edilmeleri sonucunda MDA düzeyinde meydana gelen yükselmenin anlamlı olmadığı gözlenmiştir. Benzer şekilde, $1 \times 10^{-6} \mathrm{M}$ asetamiprid ile $1 \times 10^{-5} \mathrm{M}$ d-tübokürarin karışımı, $1 \times 10^{-5} \mathrm{M}$ asetamiprid ile $1 \times 10^{-4} \mathrm{M}$ d-tübokürarin karışımı ve $1 \times 10^{-3} \mathrm{M}$ asetamiprid ile $1 \times 10^{-2} \mathrm{M} \mathrm{d}$-tübokürarin karışımının, sinirlerde MDA düzeyi üzerine meydana getirdiği artı̧̧ anlamlı değildir (Şekil 2).

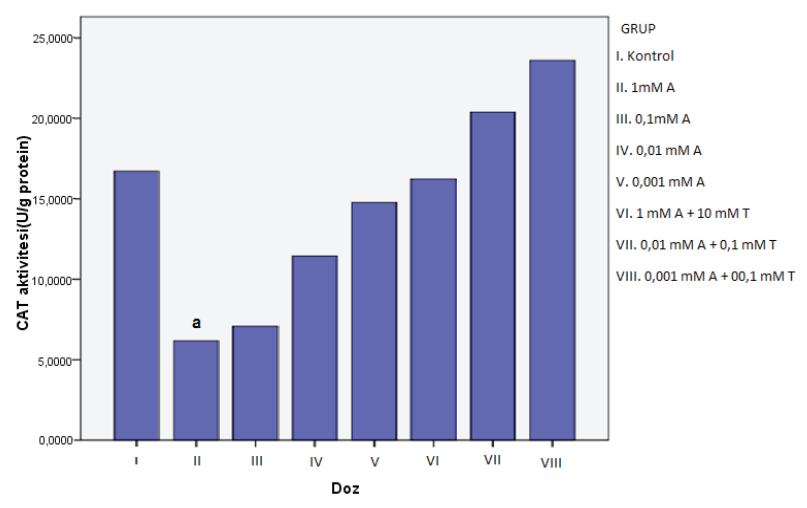

Şekil 1. Asetamiprid (A) ve d-tübokürarin'nin (T) CAT aktivitesi üzerine doza bağlı etkileri. a: Kontrol grubu ile karşılaştıııldığında $(P<0.05)$.

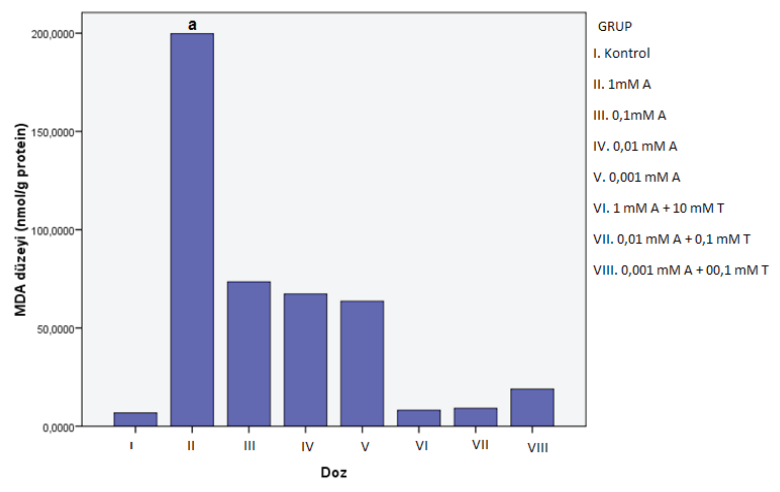

Şekil 2. Asetamiprid (A) ve d-tübokürarin'nin (T) MDA düzeyi üzerine doza bağlı etkileri. a: Kontrol grubu ile karşılaştırıldığında $(P<0.05)$.
Siyatik sinirlerin, 120 dakika boyunca $1 \times 10^{-3} \mathrm{M}$ asetamiprid ile muamele edilmesi sonucunda, AChE enzim aktivitesinin kontrol grubuna göre anlamlı biçimde azaldığı tespit edilmiştir (Şekil 3). Siyatik sinirlerin, 120 dakika boyunca $1 \times 10^{-4}, 1 \times 10^{-5}$ asetamiprid çözeltileri ve $1 \times 10^{-3} \mathrm{M}$ asetamiprid ile $1 \times 10^{-2} \mathrm{M}$ d-tübokürarin karışımı ile mumele edilmeleri sonucunda, AChE aktivitesinde meydana gelen azalmaların anlamlı olmadığı gözlenmiştir. Benzer şekilde $1 \times 10^{-6} \mathrm{M}$ asetamiprid çözeltisi, $1 \times 10^{-6} \mathrm{M}$ asetamiprid ile $1 \times 10^{-5} \mathrm{M}$ d-tübokürarin karışımı ve $1 \times 10^{-5} \mathrm{M}$ asetamiprid ile $1 \times 10^{-4} \mathrm{M}$ d-tübokürarin karışımınının sinirler üzerine uygulanması sonucunda, AChE aktivitesinde anlamlı olmayan artış meydana gelmiştir (Şekil 3).

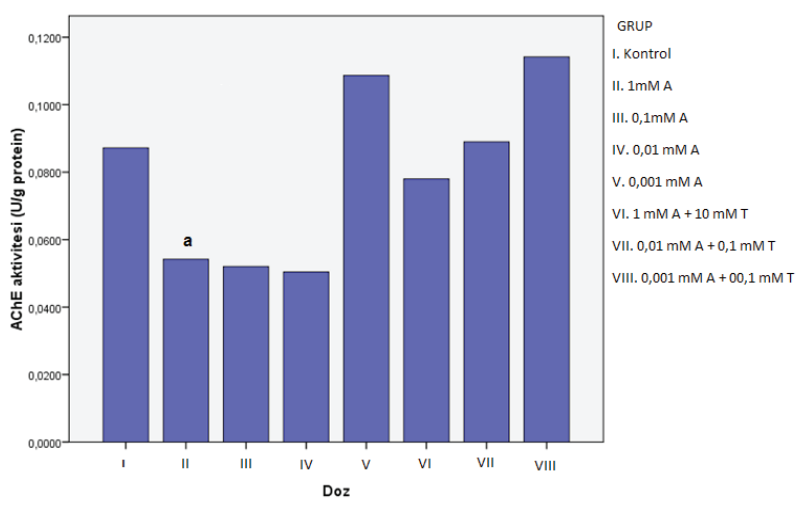

Şekil 3. Asetamiprid (A) ve d-tübokürarin'nin (T) AChE aktivitesi üzerine doza bağlı etkileri. a: Kontrol grubu ile karşılaştırıldığında $(P<0.05)$.

\section{TARTIŞMA}

$\mathrm{Bu}$ çalışmada, neonikotinoid insektisitlerden asetamiprid ve antagonisti d-tübokürarin'in kurbağa siyatik siniri üzerine meydana getirebileceği oksidatif hasar araştırılmıştır. Asetamiprid'in en yüksek olarak uygulanan $1 \times 10^{-3} \mathrm{M}$ konsantrasyonunun, siyatik sinirde biyokimyasal parametrelerden CAT ve AChE aktivitesini kontrol grubuna göre önemli biçimde azalttığı gözlenmiştir $(P<0.05)$. Buna karşılık, yapılan kolorimetrik analizler sonucunda bu konsantrasyondaki insektisitin, sinir dokuda MDA seviyesini kontrol grubuna göre önemli biçimde arttırdığı tespit edilmiştir $(P<0.05)$. Asetamiprid'in CAT, MDA ve AChE gibi biyokimyasal parametrelerde istatistiksel açıdan önemli değişiklikler yapması, bu insektisitin siyatik sinir dokusunda oksidatif hasar meydana getirdiğine işaret etmektedir (Şekil 3-1). Daha düşük dozdaki asetamiprid çözeltileri ve asetamiprid ile birlikte uygulanan d-tübokürarin 
karışımlarının, söz konusu parametreler üzerine önemli olmayan değişiklikler meydana getirmeleri ise, doza bağlı etkiyi göstermektedir.

Nikotin ve heterosiklik halkalı neonikotinoid insektisitlerden imidakloprid ile tiyakloprid'in, amerikan hamamböceği (Periplanata americana) izole torasik gangliyonları üzerine, zayıf agonist etki göstererek maksimum asetilkolin (ACh) akışını $\left(I_{\max }\right)$ \%20 ile \%25 düzeyinde arttırdığı, buna karşılık yapısında açık zincir taşıyan asetamiprid, dinotefuran, nitenpiram ve klotiyanidin'in ise, maksimum ACh akışını, \%60 ile \%100 kadar arttırarak çok daha fazla agonist bir etkiye sahip olduğu gösterilmiştir (29). nAChR üzerine selektif bir etkisi olduğu bilinen, yeni bir neonikotinoid insektisit olan klotiyanidin'in Periplanata americana afferent nöronları aksiyon potansiyeli genliği ve alanını kontrol grubuna göre önemli biçimde azalttığı, bir neonikotinoid antagonisti olan d-tübokürarin'in ise, klotiyanidin'in aksiyon potansiyeli üzerine meydana getirdiği söz konusu etkileri, nAChR üzerinden engellendiği rapor edilmiştir (30). Tip II piretroid bir insektisit olan deltamethrin $1,28 \mathrm{mg} / \mathrm{kg} / \mathrm{bw}$ dozunda ve oral yolla sıçanlara verildikten sonra, siyatik sinirde MDA düzeyi, kontrol grubuna göre anlamlı biçimde artarken, 1,28 mg/kg/bw deltamethrin ile E vitamini karışımı uygulamasında ise, CAT ve SOD aktivitesi önemli biçimde artmıştır (31). Fenitrotiyon \%25, lambda sihalotrin \%2,5 ve piperonil butoksit \%6 oranlarında karışım olarak erkek Sprague Dawley sıçanların beyini üzerine uygulandıktan sonra doza ve uygulama süresine bağlı olarak tiyobarbitürik asit reaktif türevleri, kontrol gruplarına göre önemli biçimde artmıştır (23). Neonikotinoid insektisitlerden tiyametoksam'ın Apis mellifera (bal arısı) üzerine uygulanan letal ve subletal dozu, katalaz aktivitesini kontrol grubuna göre önemli biçimde arttırmış, buna karşılık AChE aktivitesinde ise, istatistiksel olarak anlamlı olmayan bir azalmaya sebep olmuştur (32).

Nörotoksik insektisitlerin hedef bölgeleri, böcek sinir sistemindeki enzimler, iyon kanalları veya reseptörleridir (33). İnsektisitlerin, hedef bölgeler üzerine etkileri farklı olup, enzim inhibisyonundan, reseptör üzerine agonist veya antagonist etki ve iyon kanal modülasyonuna kadar oldukça fazla çeşitlilik göstermektedir (10). Organafosforlu bileşikler ve karbamatlı insektisitler, AChE enzimini inhibe ederek, sinapslarda ACh'nin postsinaptik reseptöre bağlanma sürelerini uzatırlar $(10,34)$. AChE enzimini, organofosforlu bileşikler geri dönüşümsüz inhibe ederken, karbamatlar geri dönüşümlü inhibe ederler. Her iki grup insektisit, uzayan nöroeksitasyon nedeniyle organizmayı öldürür $(10,35)$.
İnsektisitlerin, serbest radikal oluşturarak oksidatif stresi indüklediği birçok araştırmacı tarafından gösterilmiştir $(6,11,16)$. Deney hayvanlarıyla yapılan çalışmalar, pestisitlerin antioksidan enzim aktivitelerini değiştirdiği gösterilmiştir $(17,18,31,36,37)$. Neonikotinoid insektisitler, LPO'yu arttır ve bunun membran işlevini değiştirmesi sonucu, MDA gibi reaktif aldehitler meydana gelir (23, 38). Pestisitlerin oluşturduğu serbest oksijen radikalleri, LPO ve birçok oksidatif mekanizmayı uyararak dokuda hasar oluşturur $(4,13,36,39)$. Pestisitlere maruz kalan dokularda, reaktif oksijen türleri antioksidan enzimlere bağlanarak, bu enzimlerin düzeylerinde azalmaya, hatta enzim aktivitelerinde inhibisyona neden olmaktadır $(15,40)$. Cyprinus carpio (sazan balığı), karbamatlı insektisitlerden $50 \mu \mathrm{g} / \mathrm{L}$ karbofuran'a maruz birakıldıktan 7 ve 30 gün sonra, beyinde MDA düzeyi artmış, karaciğerde ise 30 gün sonra CAT aktivitesi azalmıştır (41). $10 \mu \mathrm{M}$ imidakloprid'in, dişi Wistar albino sıçanlara, intravenöz olarak enjekte edildikten 120 dakika sonra sakrifiye edilerek, karaciğer ve plazma MDA düzeyinin kontrole göre önemli biçimde arttığı gösterilmiştir (42). Çalışmamızda da siyatik sinirlerin, $1 \times 10^{-3} \mathrm{M}$ asetamiprid ile 120 dakika inkübasyonundan sonra, MDA düzeyinin kontrole göre önemli biçimde arttı̆̆1 tespit edilmiştir. 20 mg/ kg imidakloprid'in dişi Rattus norvigicus'a (sıçan) 90 gün boyunca oral yolla verilen kronik çalışmada, ovaryum izole edilerek LPO düzeyinin, kontrole göre önemli biçimde arttığ1 CAT, SOD ve GPx aktivitesinin ise azaldığı anlaşılmıştır (43). Bu çalışmada, 5 ve $10 \mathrm{mg} / \mathrm{kg}$ imidakloprid'in herhangi bir etki göstermemesine rağmen, $20 \mathrm{mg} / \mathrm{kg}$ imidakloprid'in bu parametreleri değiştirmesi konsantrasyona bağlı etkiyi göstermektedir. Bizim çalışmamızda da, en yüksek konsantrasyon olan $1 \times 10^{-3} \mathrm{M}$ asetamiprid CAT ve AChE aktivitesini azaltıp, MDA düzeyini arttırırken, daha düşük insektisit dozları ise bu parametrelerde, anlamlı bir değişiklik meydana getirmemiştir. İnsektisitlerin gereğinden fazla kullanımı sonucunda, insektisitin ya kendisi ya da dönüşüm ürünleri gıdalarda, toprak, su ve havada kalabilmektedir. İnsektisitler sulak alanlarda, toprakta ve tarım ürünleri üzerinde uzun süre bozulmadan kalırken, çevre kirliliğine neden olmakta ve besin zinciri yoluyla insana kadar ulaşan çeşitli zararlar oluşturabilmektedirler $(1,44)$.

Çalışmamızda, asetamiprid kurbağa siyatik sinirinde CAT ve AChE aktivitesini azaltmış, MDA düzeylerini ise arttırmıştır. Sinir dokusunda CAT ve AChE aktivitesinin azalması, insektisitten kaynaklanan serbest radikallere karşı, antioksidan enzim sisteminin yeteri kadar etkili olmadığının göstergesidir. Serbest radikallerin, lipit moleküllerine verdiği zararın en önemli belirteci yüksek MDA düzeyleridir. 
Bulgularımızda MDA miktarının fazla olması, asetamiprid'in sinir dokusunda oksidatif strese bağlı hasara yol açtığına işaret etmektedir.

\section{SONUÇ}

Sonuç olarak, ürün zararlılarına karşı ülkemizde ve dünyada yaygın olarak kullanılan insektisitler, sadece böcekler üzerine değil, diğer organizmalar üzerine de etkili olabilmektedirler. Çalışmamızda, neonikotinoid insektisitlerden asetamiprid'in yüksek dozunun siyatik sinir dokusunda oksidatif strese bağlı hasar meydana getirdiği gösterilmiştir. Yeni nesil olarak adlandırılan bu grup insektisitlerin de, diğer insektisitler

Investigation of Effect of Acetamiprid and d-Tubocurarine on Frog Nerve Tissue (I: Oxidative Potential)

\section{ABSTRACT}

The aim of this study is to investigate the oxidative stress effect of acetamiprid and d-tubocurarine on the sciatic nerve of Rana ridibunda by using biochemical methods. For this purpose, 40 frog sciatic nerve preparations were used in the experiments established. Frog sciatic nerves were isolated after making them spinal. Four different concentrations of acetamiprid solution $\left(1 \times 10^{-3}, 1 \times 10^{-4}, 1 \times 10^{-5}\right.$ and $\left.1 \times 10^{-6} \mathrm{M}\right)$ were applied on nerves for 120 minutes. In addition, the sciatic nerve tissues were maintained for 120 minutes in the mixture of $1 \times 10^{-3} \mathrm{M}$ acetamiprid and $1 \times 10^{-2} \mathrm{M}$ d-tubocurarine, the mixture of $1 \times 10$ ${ }^{5} \mathrm{M}$ acetamiprid and $1 \times 10^{-4} \mathrm{M} \mathrm{d}$-tubocurarine, the mixture of $1 \times 10^{-6} \mathrm{M}$ acetamiprid and $1 \times 10^{-5} \mathrm{M}$ d-tubocurarine. Nerve tissues in the control group were maintained in Ringer's solution for 120 minutes. The agonist and antagonist effects were studied gibi hedef olmayan organizmalar üzerine zararlı etkileri olabileceği düşünülmektedir. $\mathrm{Bu}$ sonuçlar, insektisitlerin tarım ve hayvancılıkta, ürün zararlılarına karşı kontrolsüz olarak kullanıldığı geleneksel yöntemler yerine, biyolojik mücadelenin uygulandığı organik tarımın yaygınlaştırılması gerektiği kanısını uyandırmaktadır.

\section{TEŞEKKÜR}

Laboratuvar çalışmalarındaki katkılarından dolayı, Mersin Üniversitesi Eczacılık Fakültesi Biyokimya A.D. Arş. Gör. Metin YILDIRIM’a teşekkür ederiz. Bu çalışma, BAP-FBE BB (SCB) 2014-2 YL koduyla Mersin Üniversitesi BAP birimi tarafından desteklenmiştir.

in the experimental group and equal number of subjects $(N=$ 5). Activity of catalase (CAT) and acetylcholinesterase (AChE) as well as malondialdehyde (MDA) levels were measured to evaluate oxidative stress in frogs.

The results of the biomarker analysis revealed that the application of $1 \times 10^{-3} \mathrm{M}$ acetamiprid on sciatic nerve significantly reduced the CAT and $\mathrm{AChE}$ activity compared to that of control group $(P<0.05)$. In contrast, it was determined that, the same concentration of the insecticide significantly increased the level of MDA on nerve tissue compared to that of control group $(P<0.05)$.

The significant reduction of CAT and AChE and significant increase of MDA in the sciatic nerve due to acetamiprid indicate that this insecticide, depending upon the oxidative stress, causes damage on peripheral nerves in high concentrations.

Keywords: Acetamiprid, d-tubocurarine, nerve tissue, oxidative stress, frog

\section{KAYNAKLAR}

1. Vural N. Toksikoloji. Ankara Üniversitesi Eczacılık Fakültesi Yayınları, No: 73, Ankara Üniversitesi Basımevi, Ankara, 2005; 334-77.

2. Kumargal D, Çömelekoğlu Ü, Aşkın A. İyon kanallarını hedef alan insektisitler. Mersin Üni Saglık Bilim Derg 2012; 5: 7-13.

3. Eddleston M, Bateman DN. Specific substances, Pesticides. Medicine 2012; 40: 147-50.

4. Aliferis KA, Jabaji S. Metabolomics - a robust bioanalytical approach for the discovery of the modes-of-action of pesticides: A review. Pest Biochem Physiol 2011; 100: 105-17.

5. Matsuda K, Buckingham SD, Kleier D, Rauh JJ, Grauso M, Sattelle DB. Neonicotinoids: İnsecticides acting on insect nicotinic acetylcholine receptors. Trends Pharmacol Sci 2001; 22: 573-80.

6. Soloway SB, Hanry AC, Kollmeyer WD, Padgett WM, Powell JE, Roman SA, Tieman CH, Corey RA, Horne CA.
Nitromethylene Insecticides, Advances in Pesticide Science. Editors: Geissbühler H, Kearney PC and Brooks GT. Pergamon Press, Zurich. 1979, pp 206-217.

7. Genper JI, Hall LM, Sattelle DB. Insect acetylcholine receptors as a site of insecticide action. Nature 1978; 276: 188-90.

8. Farooqui T. A potential link among biogenic amines-based pesticides, learning and memory and colony collapse disorder: A unique hypothesis. Neurochem Int 2013; 62: 122-36.

9. Nauen R, Kintscher UE, Salgado VL, Kaussmann M. Thiamethoxam is a neonicotinoid precursor converted to clothianidin in insects and plants. Pest Biochem Physiol 2003; 76: 55-69.

10. Scharf ME. Neurological effects of insecticides. In: Encyclopedia of Pest Management. Editor: Pimental D. Marcel-Dekker, New York. 2003, pp 1-5.

11. Klaunig JE. Alterations in Intracellular Communication During the Stage of Promotion. Exp Biol Med 1991; 198: 68892. 
12. Scassellati SG, Moretti M, Villarini M, Angeli G, Pasquini R, Monarca S, Scarselli R, Crea MG, Lonardis C. An Evaluation of Toxic and Genotoxic Risk From Work Related Exposure to Chemical Compounds. Prev Oggi 1994; 6: 125-38.

13. Banerjee BD, Seth V, Bhattacharya A, Pahsa ST, Chakraborty AK. Biochemical Effects of Some Pesticides on Lipid Peroxidation and Free-Radical Scavengers. Toxicol Lett 1999; 107: 33-47.

14. Dekkers C, Doornen VL, Kemper HG. The role of antioxidant vitamins and enzymes in the prevention of exercise-induced muscle damage. Sports Med 1996; 21: 213-38.

15. Aruoma OI. Free Radicals, Oxidative Stress, and Antioxidants in Human Health and Disease. J Am Oil Chem Soc 1998; 75: 199-212.

16. John S, Kale M, Rathore N, Bhatnagar D. Protective Effect of Vitamin E in Dimethoate and Malathion Induced Oxidative Stress in Rat Erythrocytes. J Nutr Biochem 2001; 12: 500-4.

17. Keramati V, Jamili S, Ramin M. Effect of Diazinon on Catalase Antioxidant Enzyme Activity in Liver Tissue of Rutilus rutilus. J Fish Aquat Sci 2010; 5: 368-76.

18. Yu M, Li SM, Li XY, Zhang BJ, Wang JJ. Acute Effects of 1-Octyl-3-Methylimidazolium Bromide Ionic Liquid on the Antioxidant Enzyme System of Mouse Liver. Ecotoxicol Environ Saf 2008; 71: 903-8.

19. Özeti N, Yllmaz İ. Türkiye Amfibileri. Ege Üniversitesi Basımevi, İzmir. 1994, pp 141-159.

20. Demirsoy A. Türkiye Omurgalıları-Amfibileri. Meteksan AŞ, Ankara. 1996, pp 69-73.

21. Pehlivan F. Biyofizik. Hacettepe TAŞ, Ankara. 1997, pp 167183.

22. Taillebois E, Alamiddine Z, Brazier C, Graton J, Laurent $\mathrm{AD}$, Thany $\mathrm{SH}$, Yves Le Questel J. Molecular features and toxicological properties of four common pesticides, acetamiprid, deltamethrin, chlorpyriphos and fipronil. Bioorg Med Chem 2015; 23: 1540-50.

23. El-Demerdash FM. Lipid peroxidation, oxidative stress and acetylcholinesterase in rat brain exposed to organophosphate and pyrethroid insecticides. Food Chem Toxicol 2011; 49: 1346-52.

24. Aebi H. Catalase in vitro. Methods Enzymol 1984; 105: 121-6.

25. Ohkawa H, Ohishi N, Yagi K. Assay for lipid peroxides in animal tissues by thiobarbituric acid reaction. Anal Biochem 1979; 95: 351-8.

26. Lowry OH, Rosebrough NJ, Farr AL, Randall RJ. Protein Measurement with the Folin Phenol Reagent. J Biol Chem 1961; 193: 265-75.

27. Ellman GL, Courtney KD, Andres V, Featherstone RM. A new and rapid colorimetric determination of acetylcholinesterase activity. Biochem Pharm 1961; 7: 88-95.

28. Rosner B. Fundamentals of biostatistics, Fourth ed. Duxbury Press, Boston. 1995, pp 299-344.

29. Tan J, Galligan JJ, Hollingworth RM. Agonist actions of nicotinoids on nicotinic acetylcholine receptors expressed by cockroach neurons. Neurotoxicol 2007; 829-42.

30. Thany SH. Agonist actions of clothianidin on synaptic and extrasynaptic nicotinic acetylcholine receptors expressed on cockroach sixth abdominal ganglion. Neurotoxicol 2009; 1045-52.

31. Ballı E, Yalın S, Mazmancı B, Mazmancı MA, Söğüt F, Eroğlu P, Yetkin D, Korkutan S, Çömelekoğlu Ü. Deltametrinin oluşturduğu periferik sinir hasarları üzerine E vitaminin etkisinin araştırılması. Mersin Üniv Saglık Bilim Derg 2014; 7: 17-23.

32. Beneteau AB, Carvalho SM, Brunet JL, Carvalho GA, Bulete A, Giroud B, Belzunces LP. Development of biomarkers of exposure to xenobiotics in the honey bee Apis mellifera: Application to the systemic insecticide thiamethoxam. Ecotoxicol Environ Saf 2012; 82: 22-31.

33. Bloomquist JR. Ion channels as targets for insecticides. Ann Rev Entomol 1996; 41: 163-90.

34. Casida JE, Quistad GB. Golden age of insecticide research: Past, present and future. Ann Rev Entomol 1998; 43: 1-16.

35. Acker CI, Souza ACG, Pinton S, Rocha JT, Friggi CA, Zanella R, Nogueira CW. Repeated malathion exposure induces behavioral impairment and AChE activity inhibition in brains of rat pups. Ecotoxicol Environ Saf 2011; 74: 2310-5.

36. Thapar A, Sandhir R, Kiran R. Acephate Induced Oxidative Stress in Erythrocytes. Indian J Exp Biol 2002; 40: 963-6.

37. Singh M, Sandhir R, Kiran R. Erythrocyte Antioxidant Enzymes in Toxicological Evaluation of Commonly Used Organophasphate Pesticides. Indian J Exp Biol 2006; 44: 5803.

38. Cheeseman KH. Mechanisms and Effects of Lipid Peroxidation. Mol Aspects Med 1993; 14: 191-7.

39. Kanbur M, Liman BC, Eraslan G, Altınordulu S. Effects of Cypermethrin, Propetamphos, and Combination Involving Cypermethrin and Propetamphos on Lipid Peroxidation in Mice. Environ Toxicol 2008; 23: 473-9.

40. Düzgüner V, Erdoğan S. Chronic Exposure to Imidacloprid Induces Inflammation and Oxidative Stress in the Liver and Central Nervous System of Rats. Pest Biochem Physiol 2012; 104: 58-64.

41. Clasen B, Leitemperger J, Murussi C, Pretto A, Menezes C, Dalabona F, Marchezan E, Adaime MB, Zanella R, Loro VL. Carbofuran Promotes Biochemical Changes in Carp Exposed to Rice Feld and Laboratory Conditions. Ecotoxicol Environ Saf 2014; 101: 77-82.

42. Düzgüner V, Erdoğan S. Acute Oxidant and Inflammatory Effects of Imidacloprid on the Mammalian Central Nervous System and Liver in Rats. Pest Biochem Physiol 2010; 97: 13-8.

43. Kapoor U, Srivastava MK, Srivastava LP. Toxicological impact of technical imidacloprid on ovarian morphology, hormones and antioxidant enzymes in female rats. Food Chem Toxicol 2011; 49: 3086-9.

44. MacMahon B. Pesticide residues and breast cancer. J Natl Cancer Inst 1994; 86: 572-3. 